Please do not remove this page

RMIT

UNIVERSITY

\title{
Re-thinking rural-amenity ecologies for environmental management in the Anthropocene
}

Cooke, Benjamin; Lane, Ruth

https://researchrepository.rmit.edu.au/esploro/outputs/9921862898001341/filesAndLinks?institution=61RMIT_INST\&index=null

Cooke, B., \& Lane, R. (2015). Re-thinking rural-amenity ecologies for environmental management in the Anthropocene. Geoforum, 65, 232-242. https://doi.org/10.1016/j.geoforum.2015.08.007

Document Version: Accepted Manuscript

Published Version: https://doi.org/10.1016/j.geoforum.2015.08.007

Repository homepage: https://researchrepository.rmit.edu.au

(C) 2015 Elsevier Ltd. All rights reserved.

Downloaded On 2023/04/27 00:14:21 +1000

Please do not remove this page 
Thank you for downloading this document from the RMIT Research Repository.

The RMIT Research Repository is an open access database showcasing the research outputs of RMIT University researchers.

RMIT Research Repository: http://researchbank.rmit.edu.au/

\section{Citation:}

Cooke, B and Lane, R 2015, 'Re-thinking rural-amenity ecologies for environmental management in the Anthropocene', Geoforum, vol. 65, pp. 232-242.

See this record in the RMIT Research Repository at:

https://researchbank.rmit.edu.au/view/rmit:33167

Version: Accepted Manuscript

\section{Copyright Statement:}

(C) 2015. This manuscript version is made available under the CC-BY-NC-ND 4.0 license http://creativecommons.org/licenses/by-nc-nd/4.0/.

Link to Published Version:

http://dx.doi.org/10.1016/j.geoforum.2015.08.007 


\section{Re-thinking rural-amenity ecologies for environmental management}

\section{2 in the Anthropocene}

4 COOKE, Benjamin, RMIT University, Melbourne, ben.cooke@rmit.edu.au

$5 \quad$ LANE, Ruth, Monash University, Melbourne, ruth.lane@monsh.edu

6

7 Abstract

8 The migration of lifestyle-orientated landholders (amenity migrants) to rural landscapes is resulting in the production of new rural ecologies. To date, the future implications of these ecologies for environmental management have been framed largely in 'traditional' conservation biology terms, focusing on how we can conserve or restore natural environments to a past ecological benchmark. However, the Anthropocene provides an opportunity to critically examine how we can progress environmental management in a way that locates ecologies as emergent products of human-environment interaction through time. We extend from Tim Ingold's work on wayfaring to position people and plants in environmental management as cohabitants who are traversing a world that is continually in the making. We conducted qualitative research in the hinterlands of Melbourne, Australia, involving narrative interviews with landholders and walking their property with them, using a form of participant observation called the 'walkabout' method. We found that the conservation aspirations of amenity migrants were mediated by the landscape histories that were embodied in the plants they engaged with on their property. These embodied landscape histories served to structure the trajectory of ecological emergence in which landholders were a part. We develop the concept of 'landscape legacy' to explain how past actions and future aspirations come together in management practice to produce novel and often unanticipated ecologies. Landscape legacy grounds the Anthropocene in everyday environments, capturing the need to progress environmental management as a wild experiment in rural-amenity landscapes, focusing on ecological form, function, relationship and process.

Key words: amenity migration; exurban; nonhuman agency; temporality; environmental management; Anthropocene 
35 Amenity migration is producing new rural-amenity ecologies in many post-industrial nations, as regions that were once the domain of productive agriculture now encompass a suite of aesthetic, recreational and lifestyle land uses. To date, the future implications of these ecologies for environmental management have been framed largely in 'traditional' conservation biology terms. This framing has focused on the threats or opportunities presented by rural-amenity migration for conservation or restoration of 'natural' environments to a past ecological benchmark. We suggest that the long history of human modification that characterises rural ecologies, combined with uncertainty about future ecological trajectories in light of global environmental change processes, presents an opportunity for re-framing rural-amenity ecologies and, by extension, rethinking environmental management in rural-amenity landscapes (Abrams, Gill, Gosnell, \& Klepeis, 2012; Harris, Hobbs, Higgs, \& Aronson, 2006).

Human modification of global earth systems has now seen more than three quarters of earth's biomes converted into 'anthromes' (anthropocentric biomes) (Ellis, 2013), where human use and activity are now predominant. Geographers and ecologists engaged with conservation biology research are increasingly accepting of the prevalence of anthropogenic influence, which is beginning to shift traditional notions of conservation and restoration ecology (Marris, 2011). Either directly or indirectly, an increasing proportion of research and discussion on the implications of humandominated landscapes for conservation biology has progressed via the global-scale concept of the Anthropocene (detailed below). The Anthropocene positions ecologies as temporally emergent products of human and nonhuman interactions, rather than as natural 'pre-human' artifacts (Castree, 2014). We use the Anthropocene's attentiveness to time and nonuhuman agency to re-frame the question of ecological implications for rural-amenity migration by asking: how are rural-amenity ecologies produced through interactions between people and plants over time? By grounding the Anthropocene at the scale of tangible, everyday interaction between people and plants, we deploy the concept in a way that can progress environmental management in rural-amenity landscapes in a context where pre-human notions of nature no longer apply (Castree, 2014; Lorimer \& Driessen, 2014; Ellis, 2013). 
landscapes we interrogate how local-level ecologies are produced on private properties through intimate interactions between people and plants in the hinterlands of Melbourne, Australia. To understand the temporal processes at play, we focus on how amenity migrants engage with the legacy of past human-environmental interactions embodied in the contemporary landscape in the course of their plant-based land management practices. We suggest that the way in which past human-environment interactions translate into the present and future will need to be carefully considered if we are to navigate a more reflexive approach to environmental management in the Anthropocene.

In this paper we consciously focus on the more recent phase of post-colonial land use. While acknowledging that a rich history of indigenous land use shaped Australian ecologies that have too frequently been rendered as 'wilderness', absent of human agency (Gammage, 2011; Trigger, Mulcock, Gaynor, \& Toussaint, 2008; Rose 1996), contemporary environmental management responds to the dominant transformative process set in train by more recent and intensive post-colonial land use. Moreover, as we will discuss, it is this recent landscape modification that research participants often aspire to reverse through their amenity migration.

British colonisation since 1788 has also provided a ubiquitous delineation of the 'nativeness' of Australia's flora and fauna. As a result, restoration and conservation is often framed around a return to a pre-colonial assemblage of native species (Chew and Hamilton, 2011). As has been increasingly argued, colonial demarcations of native and non-native need to be de-centred in recognition of the historically contingent and social constructed dimensions of nativeness (Ginn, 2008; Head, 2011; Mastnak, Elyachar, \& Boellstorff, 2014). This de-centring helps makes space for Indigenous Australians in the making of pre-colonial ecologies and increase management reflexivity in the Anthropocene. While we seek to contribute to this de-centring of nativeness, we retain the traditional descriptors of native and non-native (weed, introduced, invasive) to reflect the terminology used by research participants.

\section{The ecological implications of amenity migration}

The diversification of rural land use is seeing landscapes that were once valued for their productive capacity become increasingly valued for their consumptive amenity values 
102 (scenery, recreation), as an increasing number of people seek a rural lifestyle change

103 (Gosnell, 2011; Tonts, Argent, \& Plummer, 2011; López-i-Gelats, Tàbara, \& Bartolomé, 104 2009; Holmes, 2006 Paquette \& Domon, 2003). Despite a history of amenity migration 105 into rural areas stretching back to the 1970s and beyond (Curry et al., 2001), its recent 106 acceleration has brought a range of land use and environmental management issues to 107 the forefront of policy and academic debate (Abrams, Gill, Gosnell, \& Klepeis, 2012; 108 Larsen, Sorenson, McDermott, Long, \& Post, 2007; Barr, 2005).

110 Amongst the issues associated with amenity migration have been concerns about the 111 types of new rural-amenity ecologies that will emerge as a result of changing land use 112 (Abrams et al, 2012). As noted above, the rural landscape changes associated with 113 amenity migration have been largely framed in terms of positive or negative future 114 implications for the natural environment. The negative ecological consequences centre 115 on the potential for species loss and ecological fragmentation as farmland is sub-divided 116 into small lifestyle-orientated lots (Argent et al., 2010). Negative implications have also

117 been raised regarding the preferences of some amenity migrants to pursue management for recreational purposes, resulting in the retention of species for aesthetic reasons over institutional environmental management efforts aimed at

120 'bringing back' a rare species (Urquhart \& Courtney, 2011; Knoot, Schulte, \&

121 Rickenbach, 2010; Van Auken, 2010).

123 Running counter to the narrative of negative ecological 'impacts' are suggestions that 124 rural-amenity migration is actually catalysing ecological restoration and conservation 125 activities. A motivation to preserve and restore native ecologies is an aspiration for a 126 host of rural-amenity migrants (Cooke \& Lane, 2015; Mendham, Curtis, \& Millar, 2012; 127 Gill, Klepeis, \& Chisholm, 2010). Indeed, some landholders purchase rural property with 128 the express intention of pursuing conservation as their core land use activity (Yung \& 129 Belsky, 2007; Jackson-Smith \& Kreuter, 2005). At a regional level, ecological 130 regeneration has been reported in select rural areas that have seen an increase in 131 amenity migration and a reduction in intensive agriculture in recent decades (Walker, 132 Marvin, \& Fortmann, 2003).

134 We view the 'positive/negative ecological futures' framing of emerging rural-amenity 135 ecologies as problematic for two central reasons: First, it ignores the long history of pre 
136 and post colonial human modification that has shaped rural-amenity landscapes in

137 myriad ways, presupposing that a benchmark nature can indeed be recreated amidst

138 this biophysical transformation, and 2) there is limited sensitivity to the uncertainty

139 and unpredictability characterising the processes of global environmental change (Ellis,

140 2015; Head, 2011).

141

142 The Anthropocene provides a useful provocation for de-centering conservation biology

143 by advancing a cross-disciplinary discussion about future environmental management

144 in ways that resonate for rural-amenity landscapes. While the hallmarks of the

145 Anthropocene that signify the end of the Holocene era continue to be debated by

146 geologists and environmental scientists, its conclusion is said to mark the phase in

147 which earth systems have become largely overwhelmed by human activity (Kareiva,

148 Lalasz \& Marvier 2011). If the natural world has been consigned to the now departed

149 Holocene, the Anthropocene requires us to de-centre traditional ecological benchmarks

150 as the reference point for environmental management, reflecting instead that ecologies

151 are emergent products of human-environment interaction (Castree, 2014; Head et al.,

152 2015; Lorimer and Driessen, 2014; Robbins and Moore, 2013). Such a conception is

153 particularly relevant for rural-amenity landscapes, given the often complex and

154 multiple successions of landscape modification and habitation they embody.

156 While a framing of rural-amenity ecologies as emergent helps us to de-centre traditional 157 notions of conservation biology, key questions remain: 1) In what specific ways are

158 ecologies produced through human-environment interaction in rural-amenity

159 landscapes, and; 2) what are the implications for environmental management theory

160 and practice in heavily modified landscapes?

\section{Temporality, nonhuman agency and environmental management practice}

163 We argue that the tangible and intimate interactions between people and the

164 environments in which they live are an essential starting point for interrogating rural-

165 amenity ecologies in the Anthropocene. As Halfacree (2006, p309) notes, 'relationships

166 between land and everyday life' are critical in the making and re-making of rural

167 landscapes over time. However the ecological implications discourse has so far

168 progressed with limited attention to the tangible relationships between amenity

169 migrants and the landscapes they inhabit (for a notable exception see Gill, Klepeis, \& 
170 Chisholm, 2010). As a result, the inter-relationship between people, biophysical

171 environments and time in the production of rural-amenity ecologies has been under-

172 examined (Abrams et al., 2012; Gill et al., 2010). The environmental management

173 practices of rural-amenity migrants on their properties can offer a starting point for

174 exploring how these inter-relationships contribute to ecological emergence (Holmes,

175 2006). We define environmental management practice at this fine-grained scale as any

176 form of interaction between landholder and landscape - motivated by a conservation

177 aspiration or other broader amenity land use aspiration - that shapes ecological

178 assemblages. As rural-amenity migrants appear to be most interested in engaging in

179 environmental management on their own private property parcel, as opposed to public

180 land, this space of everyday landscape interaction is the focus for this research (Cooke 181 and Lane, 2015).

182

183 The nonhuman agency of most interest for this paper is the form, habit and lifecycle of

184 plants. While plants may be agents acting without intentionality, their change or

185 continuity through time not only shapes the landscape, but shapes human perception

186 and engagement with the landscape (Head \& Atchison, 2008). We concentrate on plants,

187 because the making of new rural ecologies for aesthetic, recreational or ecological ends,

188 centres on flora. Whether it is planting, tending or removing vegetation, landholders are

189 interacting directly and tangibly with plants through these practices.

191 We note that there are strong parallels between emerging rural-amenity ecologies and

192 the interaction of people and plants in domestic and community gardens, as both

193 represent ecologies that have been intensively inhabited over time. Gardening has been

194 positioned as a form of 'conversation' between human and nonhuman actors through

195 which the active and ongoing experience of gardening changes both gardens and

196 gardeners (Doody et al., 2014; Head and Muir, 2006; Power, 2005). Past people-plant

197 relations have also been shown to be pertinent for influencing contemporary

198 management in long-running community gardens, where planting arrangements have

199 been established through the labour of gardeners who have since moved on (Barthel et

200 al., 2010). While those gardeners may no longer be present, the form and arrangement

201 of plants mediates the way the garden is tended by a new generation of gardeners,

202 connecting past people-plant relations to those in the present. How rural-amenity

203 migrants engage with the histories of landscape modification embodied by the plants 
204 they encounter may provide important insights into how dynamic, emergent ecologies 205 are being produced.

206

207 4. Inhabiting ecologies - locating people-plant relationships through time

208 To be useful for understanding rural-amenity ecologies and environmental

209 management practices, the Anthropocene concept must be brought to ground in the

210 fine-grained interactions between people and plants. To achieve this we connect with

211 the work of anthropologist Tim Ingold, who has sought to re-embed human perception,

212 knowledge and experience in the contextual 'lifeworlds' that people inhabit (Ingold,

$2132000,2011)$. A core tenant of Ingold's work is the notion that human perception of the

214 environment is indivisible from our experiences of that environment (Ingold, 2011).

215 Through the term 'wayfaring' Ingold suggests that movement along lines of becoming

216 defines human existence, as we traverse through the world with other human and

217 nonhuman inhabitants (Ingold, 2007, 2011). Thus, 'inhabiting' the world is not being in

218 place, but rather 'movement along a way of life' (Ingold 2011, p4, emphasis our own).

219 Where the 'lines' of different inhabitants intersect, the 'life of each becomes bound up

220 with the other' (Ingold 2011, p148) in a meshwork. Imagining environmental

221 management as an enmeshing of the lines of movement of people and plants (both

222 through space and over time) gives management a dynamic sensibility in keeping with

223 the Anthropocene. It also raises a pertinent question for environmental management in

224 the Anthropocene: what are the epistemological implications of meshwork interactions

225 for understanding how perceptions of ecological function are generated and

226 appropriate management interventions are produced?

227

228 Ingold's work on wayfaring makes two substantive contributions to our research

229 framing. First, it captures an active engagement with the environments of our everyday

230 lives that can inform an interrogation of environmental management practice (Ingold,

231 1993, 2011). This helps us to think about environmental management practice as a

232 'performative achievement' (Jones \& Cloke 2008, p84) rather than a static, outcome-

233 orientated process. It also helps to understand how landholders' initial aspirations for

234 management are mediated by their tangible engagements with plants that grow, spread

235 and change over time. Emphasising lines of movement also guards against a positioning

236 of the property parcel as a bounded ontological space of human-environment

237 interaction (Massey, 2005). Second, wayfaring brings a sense of temporality to land 
management and the process of rural ecological change. The temporal aspect of landscape interactions highlights that to inhabit a landscape is to occupy a space that embodies a succession of past human and nonhuman inhabitants. In this sense, 'past

241 patterns of action' (Gosden \& Head, 1994, p114) in the landscape are recognised for

242 their potential to structure future ecologies, as well as structuring the way current

243 human inhabitants move through and perceive ecologies in the process of

244 environmental management (Ingold, 2011).

245

\section{5. Methodology}

\section{Study Site}

248 The site of this research project was the hinterlands of Melbourne, Victoria, Australia.

249 This was an appropriate research setting due to the increasing pace of rural-amenity 250 land use transition in this region (Mendham \& Curtis, 2010). In Victoria, coastal and coastal hinterland areas within commuting distance to Melbourne have experienced especially strong amenity migration (Argent et al., 2010). Increasing property prices and land subdivision have characterised both regions in recent decades, with land in one of the study areas (East Corangamite) nearly twice the price per hectare of land of similar size and productive potential further to the west of the catchment, suggesting a high amenity premium for land in this region (Mendham \& Curtis, 2010) (Figure 1). All but five of the participants in this study had bought property that had been subdivided

258 from a larger farming property, with the remainder purchasing small farms that were no longer viable in an expanding global agricultural sector. Price rises and property subdivision are largely indicative of rural-amenity migration in post-industrial nations (Abrams et al., 2012; Yung and Belsky, 2007), though smaller farms can remain intact

262 when sold to amenity landholders (Gosnell et al., 2006).

While no specific financial data was collected from participants, the stories of their upbringing, previous homes and working life that punctuated the interviews suggested participants in this study came from a wide socio-economic spectrum. Despite property prices generally being on the rise in Australia, rural-amenity land prices remain competitive in relation to the urban property markets of capital cities, resulting in a relatively diverse socio-economic profile amongst newcomers to many regions (Ragusa, 2010). Indeed, an important component of amenity migration amongst early retirees stretching back to the 1970s in Australia has been the availability of cheap land in close 
272 proximity to urban centres (Curry et al., 2001).

273

274 While gentrification of rural landscapes is certainly occurring in Australia, with

275 absentee and retiree property ownership on the rise (Race et al., 2010), it may not be as

276 pronounced as the US, where amenity migration is often framed as the buy-up of rural

277 land by wealthy individuals seeking to deploy capital they have accumulated in the city

278 (Walker and Fortman, 2003). This characterisation shares much in common with the

279 extensive rural gentrification literature from the UK, detailing the displacement of

280 working rural landscapes and those who work them by wealthy in-migrants (Marsden

281 et al., 2003). The similarities and differences between this case and other contexts

282 reinforce the uneven spatial, structural and political economic characteristics of

283 amenity migration across post-industrial nations (Cocklin \& Dibden, 2006), and the

284 associated challenges of generalising research results from any given case. Yet, there is

285 some consistency across a range of studies concerning land management; conservation

286 and restoration that focuses on the private property parcel is a common motivation for

287 amenity migrants, suggesting some degree of similarity to how landholders come to

288 engage with the ecologies on their property for generating understandings of ecological

289 function and appropriate environmental management (Cadieux, 2011; Cooke \& Lane,

290 2015; Gill et al., 2010; Urquhart \& Courtney, 2011; Van Auken, 2010; Yung \& Belsky, 291 2007).

292 


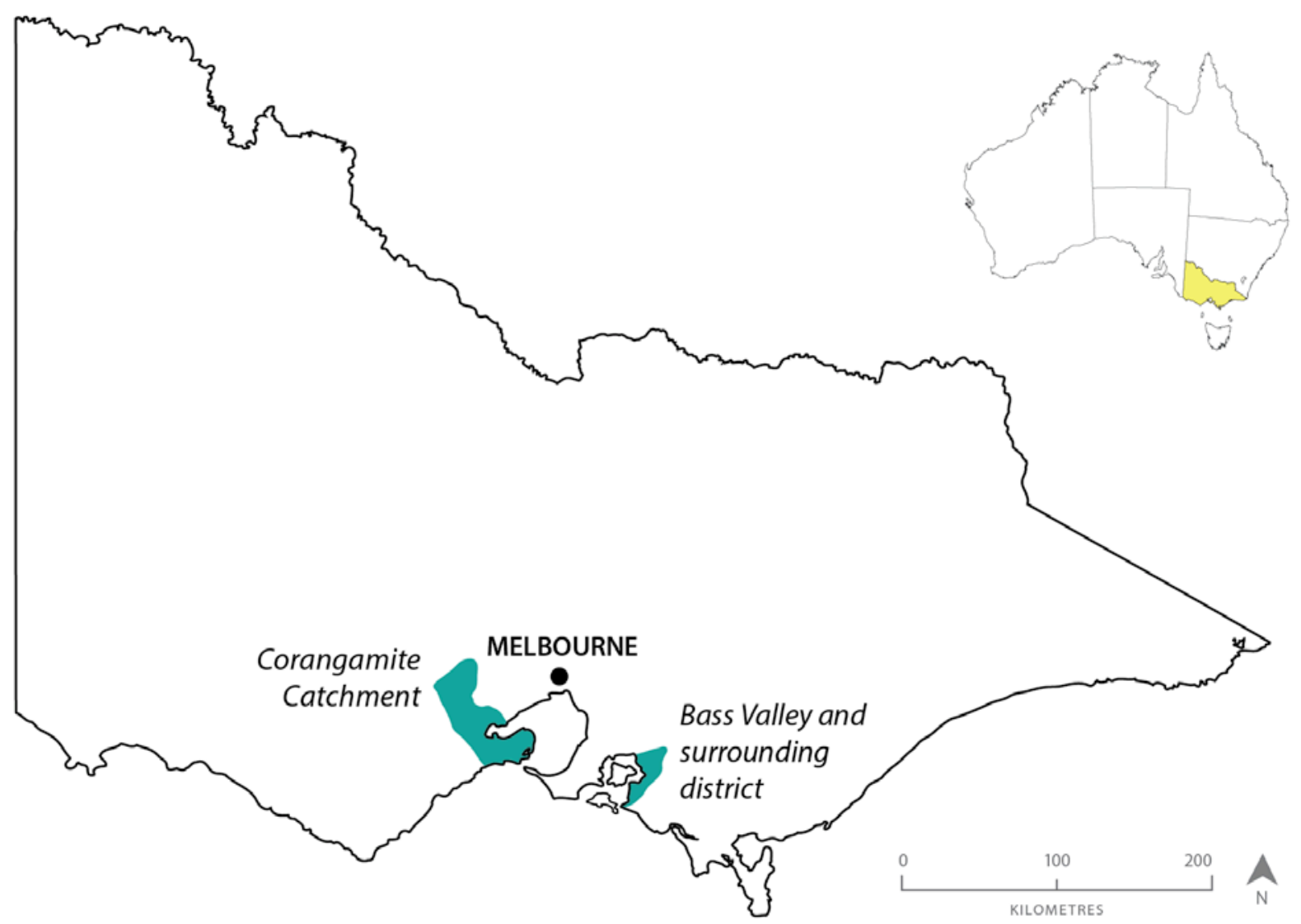

Figure 1. The case study regions with Melbourne's hinterland that were explored in this study.

296 The landscapes of both East Corangamite and the Bass Valley are characterised by historical agricultural modification. The influence of farming is evident in the presence of paddocks, farm fencing, livestock and pastures that have thoroughly transformed these landscapes since British settlement. Diary and cattle farming have traditionally dominated the rolling hills and high rainfall area of the Bass Valley, while the comparatively drier and flatter East Corrangamite has been the site of sheep grazing and cropping. Despite their varying agricultural trajectories, both regions have seen significant clearance and conversion of forests and grasslands in the making of their current ecological arrangement. Alongside the process of amenity migration (Mendham \& Curtis, 2010; ABS, 2006), both regions are subject to local and regional environmental programs that are seeking to increase the quality and extent of native ecologies (CCMA, 2003). This includes efforts to encourage private landholders to take up conservation and restoration projects on private land, in an effort to improve ecological function at a landscape scale. The combination of amenity migration, highly modified landscapes and active efforts to encourage landholders to participate in restoration makes these regions ideal for exploring the processes of ecological emergence. 
Research methods and participants

314 A total of 21 landholders were interviewed between June and October 2010 in the two 315 localities shown in Figure 1. 2. Participants had resided on their properties for varying 316 lengths of time, ranging from six years to over 20 years. This provided a wide time

317 frame over which the management practices of landholders had been conducted and

318 reflected upon. Most participants had moved from suburban Melbourne, with three 319 moving from small properties in rural townships. Three landholders had some previous 320 farming experience, with two having retired on the property they previously farmed.

321 The varying ecological characteristics of landholders' properties are evident from the

322 figures contained within the following section which reinforce the heterogeneous

323 ecologies that have resulted from a long history of rural landscape modification. Details

324 of all participants are listed in Table 1, including their initial intentions for

325 environmental management upon migrating to their property, which serves as a useful

326 counterpoint for the types of practices and ecologies that emerge in the following

327 section.

Research participants were recruited primarily from people who participated in private land conservation schemes in Victoria, as the wider research project involved an exploration of how these programs were enacted by participants. While this somewhat explains the commonality of ecological restoration motives to all participants, there was one cohort of participants (six people) who did not participate in any programs, yet still undertook restoration. These participants were recruited via direct letter drops to properties in the study areas. Given this program adoption, it is reasonable to expect the participants had a higher level of conservation interest than a random sample, though it should be noted that all six participants who had not been involved in a conservation scheme were also active land managers. 
Table 1. Research participants and their management aspirations upon in-migration.

\begin{tabular}{|c|c|c|c|}
\hline Participant/s & Age & $\begin{array}{l}\text { Environmental management aspiration upon in- } \\
\text { migration }\end{array}$ & $\begin{array}{l}\text { Length of } \\
\text { Tenure }\end{array}$ \\
\hline $\begin{array}{l}\text { Alex \& } \\
\text { Simone }\end{array}$ & $30-39$ & $\begin{array}{l}\text { Leave forested areas intact and plant linear tree buffers } \\
\text { around paddocks }\end{array}$ & 14 years \\
\hline Alice \& Sam & $50-59$ & Remove weeds from creek line & 14 years \\
\hline Dan & $70-79$ & $\begin{array}{l}\text { Plant linear tree buffers to shelter livestock and forest patches } \\
\text { to increase forest cover }\end{array}$ & 28 years \\
\hline Emma & $70-79$ & $\begin{array}{l}\text { Establish garden and allow natural regeneration of former } \\
\text { pine plantation }\end{array}$ & 26 years \\
\hline Hannah & $40-49$ & Allow woodland to regenerate and establish garden & 18 years \\
\hline Jeff \& Claire & $50-59$ & Leave forested area and establish garden & 14 years \\
\hline $\begin{array}{l}\text { Jim \& } \\
\text { Beatrice }\end{array}$ & $40-49$ & Conserve existing forest ecology on the property & 15 years \\
\hline Karen & $70-79$ & Re-plant under storey vegetation amongst scattered trees & 13 years \\
\hline Kelly & $60-69$ & $\begin{array}{l}\text { Conserve existing forest and plant out open areas around the } \\
\text { house }\end{array}$ & 11 years \\
\hline Ken & $50-59$ & Actively restore woodland to former grazing land & 6 years \\
\hline Lauren & $40-49$ & Plant under storey in open paddock & 22 years \\
\hline Liz & $50-59$ & $\begin{array}{l}\text { Conserve existing forest and allow natural regeneration of } \\
\text { paddocks to continue }\end{array}$ & $20+$ years \\
\hline Maddy & $50-59$ & Allow grazing land the regenerate and establish garden & 8 years \\
\hline Martina & $40-49$ & Retain existing forest and plant along fence line & 17 years \\
\hline Nick & $50-59$ & Revegetating woodland, planting garden and orchard & 7 years \\
\hline $\begin{array}{l}\text { Pauline \& } \\
\text { Allan }\end{array}$ & $40-49$ & Plant linear tree buffers to shelter livestock & 12 years \\
\hline Rob & $50-59$ & Leave forested area largely untouched & $20+$ years \\
\hline Sally & $40-49$ & Leave forested area and establish garden & 8 years \\
\hline Steve & $50-59$ & Leaving forest to regenerate and planting under storey & 9 years \\
\hline Tina & $50-59$ & $\begin{array}{l}\text { Replant forest to former grazing land, establish garden and } \\
\text { orchard }\end{array}$ & 22 years \\
\hline Trevor & $70-79$ & $\begin{array}{l}\text { Leave open paddocks and plant linear tree buffers to shelter } \\
\text { livestock }\end{array}$ & $20+$ years \\
\hline
\end{tabular}

351 We pursued a qualitative research project that adopted two primary research methods;

352 narrative interviews and a form of participant observation called the 'walkabout

353 method' (Strang, 2010). The narrative approach to interviews aimed to encourage

354 landholders to tell stories about their experiences and interactions with the local

355 landscape over time (Rosenthal, 2004). Narrative interviews were useful in efforts to

356 understand how people's property landscapes and surrounding regions had changed

357 over time, with a focus on significant events or experiences that illustrated these

358 changes. Narrative interviews were selected in accordance with their use in oral history

359 research, where participants are encouraged to tell stories about their past. This

360 storytelling approach was adapted to encourage landholders to tell stories about

361 landscape change and plant interactions. In advance of the interview, participants were

362 also encouraged to locate any photographs they had of their property at the time of

363 arrival, which could be used as a prompt for stories about how the landscape had

364 changed and by what means. Interviews were conducted in or around the home of the 
participant.

The walkabout method - exploring human-environment interactions

368 Following the narrative interview, the researcher (first author) walked participants' properties with them to expand on the discussions of landscape change and management practices that had already taken place. This 'walkabout method' (Strang, 2010) recognises that material environments that are of importance to people will embody memories and experiences of interactions with those spaces. Moreover, in keeping with a traditional 'field studies' approach, the walkabout method recognises the value of observation and informal conversations in the spaces of relevance for people's actual practices (Doody et al., 2014; Kvale \& Brinkman, 2009). Allowing the landscape to serve as a repository of memory for landscape change and management activity provided significant insights into the complex process of land management. For example, being able to compare a landholder's first planting with their most recent efforts, and then talking about how these changed practices had come about, provided critical insight into the temporal dimensions of management practice. It also brought a sense of movement to inhabiting the landscape, as we traversed tracks from one management space to the next. Indeed, participants noted the presence of 'weedy' plants considered as we walked the property, with five participants gravitating toward specific property spaces to inspect the weeds and remove them by hand.

The walkabout method also attributed some agency to the landscape as a participant in the research process. Observing the evidence of ecological change over time (remnant vegetation or past efforts at revegetation, for example), the varying growth patterns and fortunes of different plants, competition between different species for resources and evidence of plant regeneration and spread over time became evident. Direct observation of the lives of plants could then be compared to how landholders' perceptions and practices had been shaped by encounters with plants as they inhabited their property. Observing the physical outcomes of management practice also provided evidence of how management practices had shifted over time. Property walks averaged around two hours in length.

397 While we focus on plant agency for the purposes of this paper, it is important to note 398 that there are many other nonhuman actors in the landscape that also interact with 
people to produce ecologies. For example the presence (or absence) of fauna may play a

400 vital role in shaping future ecologies. How ecologies emerge through observation,

401

402

403

404

405

406

407

408

409

410

411

412

413

414

415

416

417

418

419

420

421

422

423

424

425

426

427

428

429

430

431

432

\section{5}

presence, interaction and absence of fauna warrants scrutiny for progressing

environmental management. Analysis of abiotic elements like soil and weather as actors in the landscape would also likely yield insights into ecological emergence, especially when we consider their role as contingent agents in the making of plants (Head et al., 2014; Knapp \& Fernandez-Gimenez, 2009).

\section{Inhabiting the embodied histories of landscapes}

The form and arrangement of heavily modified rural-amenity ecologies presented the perfect canvas for many participants to further their aspirations for 'bringing back' native ecologies to the landscape. Seven participants stated explicitly that they thought their in-migration would allow the return native nature to a rural landscape that had long been 'over-worked' through farming practices. Alan's declaration that 'people spent decades clearing the land here and we'll spend decades revegetating it' captured the broad redemptive aspiration that many participants brought with them to their new surroundings (See Table 1). However, our exploration of their efforts to bring these imported aspirations to fruition revealed the extent to which landholders are not the only actors contributing to the making of new ecologies. Throughout this section we heavily foreground the role of plant agency in the co-production of rural-amenity ecologies. This foregrounding achieves two goals: 1) to redress the general neglect of nonhuman agency in environmental management scholarship, and 2) exemplify the 'power' (Head \& Atchison, 2008, p\#) of plants in disrupting and re-orientating the ecological aspirations of human actors. We work through three separate examples, each exploring a particular element of the agency of plants. 6 


\subsection{How past people-plant relations are brought into the present}

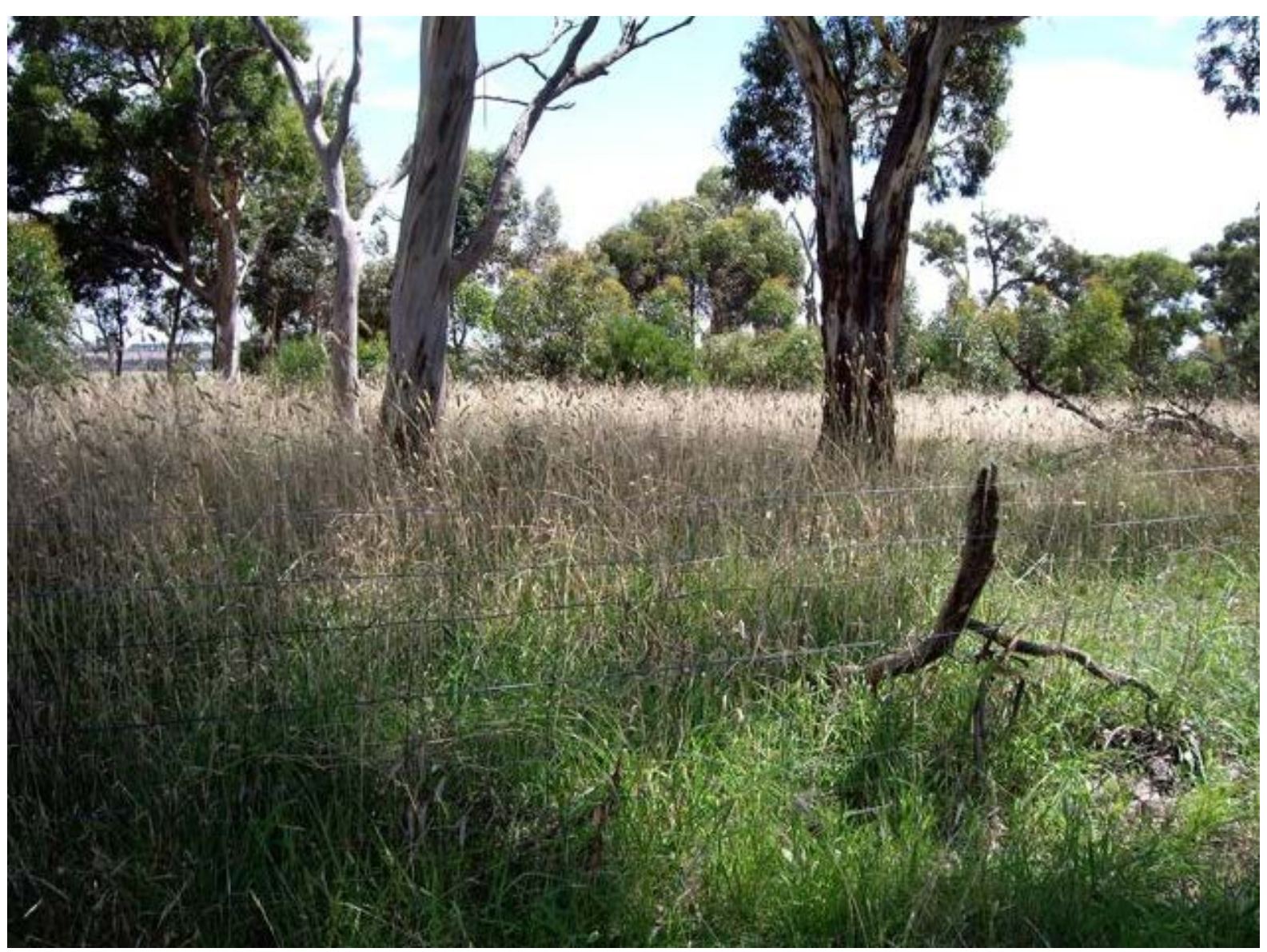

434

435

436

437

438

439

440

441

442

443

444

445

446

447

448

449

450

451

452

Figure 2. Sugar Gums (Eucalyptus cladoclyx), located rear centre and right of the image, are beginning to fill the open paddock space in the foreground, that had initially set aside for the natural regeneration of the local the Yellow Gum Species (Eucalyptus leucoxylon).

Despite being less than a decade old, the Sugar Gums (Eucalyptus cladoclyx) that are establishing in Trevor's paddock are beginning to express a characteristic form. The dense timber contained in their single straight trunks - abnormally straight for eucalypt species - are already supporting dense, deep-green foliage. Combined with the wide, outward growth habit of the limbs, the foliage helps to buffer the wind that blows across the open grassy plains. The relative flourishing of the Sugar Gums during this period of time is notable, in comparison to the fortunes of other species over the same period, as south-eastern Australia experienced a particularly harsh period of drought that began in the early 2000s. Endemic to regions of South Australia notable for a dry climate, Sugar Gums possess a tolerance to drought that is distinguished even amongst eucalypt species. Indeed, the contrasting fortunes of different eucalypt species during the drought, reflected by the death of at least one of the locally endemic mature Yellow Gums (Eucalyptus leucoxylon) in the foreground of Figure 2, reveal how Sugar Gums came to occupy a section of Trevor's paddock. 
454 The fenced section of paddock was originally intended to be home to Yellow Gums that would regenerate from seed stores that were likely still present in the soil, once sheep were excluded. In the 1990s, a local natural resource management (NRM) group gave Trevor a small grant to facilitate this regeneration. As the denoted endemic large tree species for the region, Yellow Gum restoration is encouraged. Conservation groups and NRM agencies in Victoria rarely advocate for Sugar Gum planting, given the species is endemic to South Australia and therefore not 'indigenous'. Moreover, the dense timber yielded by Sugar Gums, which is prized for its fence posts and firewood, does not readily form good hollows for local wildlife (Hamilton, 2001). However, in the years following, virtually no Yellow Gums self-seeded, and the fenced area became choked with pasture grass that spread from adjoining paddocks. As the drought began to take hold, the lack of natural regeneration became a secondary concern, as the mature Yellow Gums died back. While the causes of the Yellow Gum dieback are likely to be multiple, it was the overlap with the drought period that proved significant in the re-making of this local ecology.

Dieback of the Yellow Gums was contrasted by the persistence of some large old Sugar Gums in Trevor's yard, which were planted by the previous property owner. These mature Sugar Gums remained healthy through the early years of the drought with little to no tending. Visible from the lounge room and casting shade across the pathway from home to shed, the imposing persistence of the Sugar Gums was an ingrained component of Trevor's everyday activities. It was this persistence that saw Trevor plant the Sugar Gums that are visible in Figure 3, in lieu of the lack of natural Yellow Gum regeneration. Trevor was aware of the attitude that conservation agencies had towards Sugar Gums, but his lived experience of the robustness character of these trees through adverse conditions took precedence.

The persistence and durability of Sugar Gums in the landscape demonstrated the capacity of these plants to actively propagate to other parts of the property. Trevor's planting of Sugar Gums in a new part of the property produced a rural-amenity ecology that is novel in its arrangement and location, while also being structured by the continuity with previous trees of this species and with the actions of a past landholder. In this sense, the habitation of the previous landholder is being extended but also re- 
interpreted by Trevor in the making of a rural-amenity ecology. Through inhabiting the

488 landscape with the Sugar Gums over time, Trevor's perspective shifted on what types of 489 species should be restored in the landscape. The proliferation of Sugar Gums reinforces 490 that trees often persist along a timeline that far exceeds that of human life, showing how 491 people-plant relations can connect through multiple generations via the lifecycle of the 492 plant (Lien and Davison, 2010). The capacity of plants to prosper in the changed and 493 changing climatic conditions of the Anthropocene, in combination with the multitude of 494 landscape alterations embodied in rural-amenity landscapes, suggests that drought 495 tolerance is a highly desirable characteristic for future environmental management 496 (Mastnak et al., 2014; Young, 2014).

497

\subsection{Working with and against historical trajectories of land management}

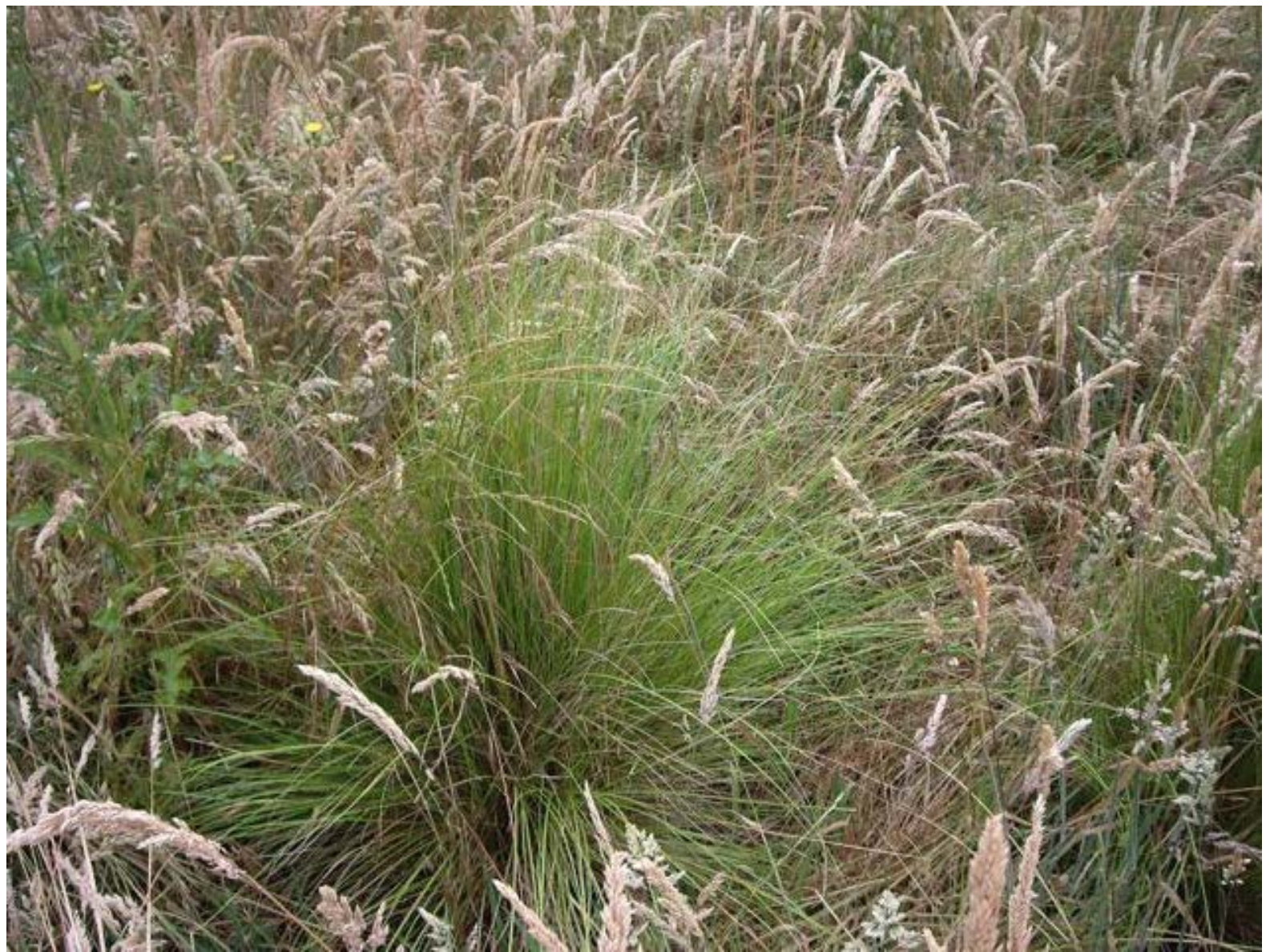

Figure 3. A green tussock of native Poa (Poa labillardierei) planted by Nick (lower centre image) as part of a restoration project struggles to establish itself amidst the surrounding pasture grasses, dominated by Cocksfoot (Dactylis glomerata) (light sandy-coloured seed head). This photo was taken around two years after the restoration project began.

504

505 Soil seed banks play an unseen role in the ecology of plant assemblages. The seeds of

506 plant species can lay dormant in the soil for extended periods, germinating quickly in

507 response to disturbances like fire, or changes in soil moisture (Wang et al., 2013). This 
508 applies to both native species and those that have been imported, such as the host of 509 pasture grass varieties from Europe, Africa and the Americas. The soil seed bank of 510 pasture grasses such as Cocksfoot, pictured in Figure 3, can persist in the soil for up to

511 four years, making it difficult to remove when attempting ecological restoration projects

512 (a relatively short duration compared to many native seeds) (Farm Future Industries

513 CRC, 2011). Over a century of grazing and cropping in the region pictured above

514 suggests a soil seed bank dominated by pasture grass seed. In this sense, the history of

515 landscape modification that is visible above the ground is reflected below the ground, in

516 the soil profile.

517

518 While the history of landscape modification embodied in the soil is out of sight, it is not 519 out of mind. When conducting ecological restoration projects like the one taking place 520 on Nick's property, pasture grasses are sprayed with herbicide to knock down the 521 existing grasses and exhaust the seed bank. In this case, the initial knock down proved 522 successful, which paved the way for the sowing of native grass seeds and seedling, along 523 with the planting of canopy tree seedlings, to replicate the pre-colonial grassy forest 524 vegetation community of the area. While heavy rain that followed the initial planting 525 triggered growth of native grasses and trees, it also helped to germinate the Cocksfoot 526 from soil seed. This initial flush of growth from the seed bank has resulted in 527 competition with the native grasses for light, space and nutrients. While some Cocksfoot 528 has undoubtedly blown in on the wind from surrounding paddocks, the dense swathes 529 of Cocksfoot that quickly established underscored its abundance in the soil seed store. 530

531 Despite the thick growth of Cocksfoot grasses, the Yellow Gums that had been sparsely 532 planted across the site in line with the imagined grassy forest ecological restoration, 533 established quickly and broke through the mat of grasses (Figure 4), in contrast to the 534 struggling native Poa's pictured in Figure 4. The capacity of the Yellow Gums to 535 overcome the choking constraints of the rejuvenating Cocksfoot proved a trigger event 536 for the rural-amenity ecology on Nick's land. Experiencing this Yellow Gum growth led 537 Nick to plant more of these Gums as he felt they 'did well' and sometimes 'you've just 538 got to plant the stuff that survives in the ground'. According to Nick, during an annual 539 site visit, the conservation officer responsible for overseeing his restoration project 540 voiced displeasure at the increased density of eucalypts, suggesting that the site no 541 longer reflected a grassy forest ecology. 


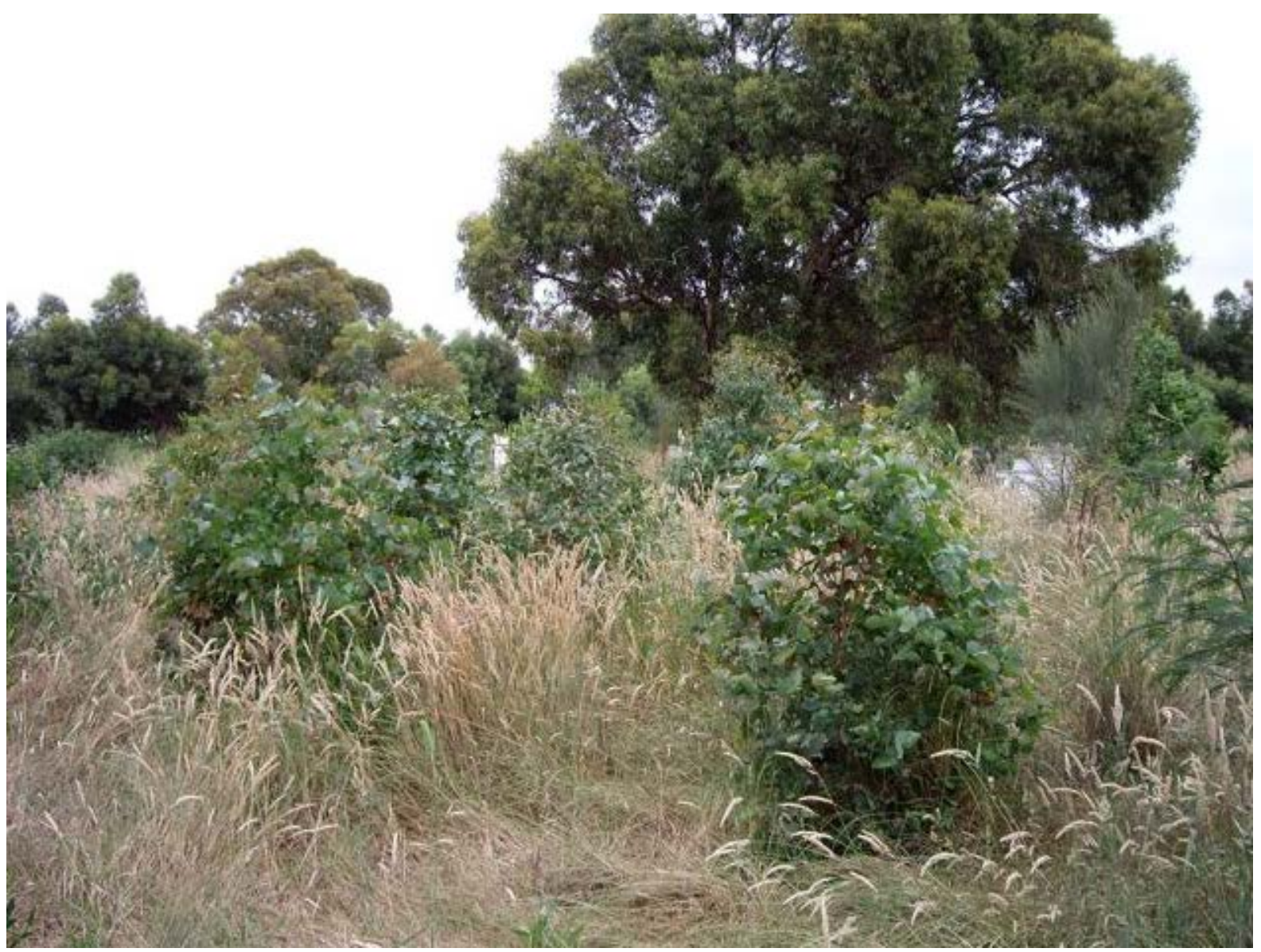

543 Figure 4. Nick planted additional Yellow Gums in a section of his restoration project as they were

544 establishing successfully amongst the introduced pasture grasses. A mature eucalypt can be seen at the 545 rear of the photo.

547 The rural-amenity ecology emerging here reveals a tension between a soil seed bank

548 that embodies a history of landscape modification, and the redemptive ecological

549 restoration aspirations that Nick initially sought to realise. Nick's aspiration for

550 restoring a past ecology was catalysed by the ecological restoration program, driving

551 the attempts to re-create a pre-colonial ecology. However, the seed store of Cocksfoot -

552 a hidden and dormant form of plant agency - proved an immediate and powerful actor.

553 The constant replenishment of the seed store over the decades of its cultivation,

554 activated in a harmonised flush of growth, had shifted the trajectory of environmental

555 management in a period of less than two years. Just as notably, as Cocksfoot

556 materialized, Nick's practices shifted from management aimed at bringing back a past

557 ecology, to prioritising the species that 'did well' in this landscape. The prominence of

558 the Yellow gums rising above the grasses as we walked Nick's property gave a sense of

559 how Nick's management practices would be affected by experiencing this growth over

560 time; the capacity of the gums to persist and then flourish represented an avenue for a

561 future ecological trajectory that worked with the historical ecology that was already 
562 given.

563

564 Ecological restoration in the Anthropocene must reflect carefully on the suitability of

565 the plants we consider for restoration amidst the plant agency that may lie dormant in

566 the soil. While site preparation, like weed spraying, is common practice for many

567 environmental management practitioners, we cannot think about these practices as

568 making space for the re-creation of a pre-colonial ecological assemblage. The suitability

569 of restoration species and the assemblages in which they are planted will be partly

570 dictated by the embodied histories of landscape change. Moreover, the challenges and

571 unpredictability of environmental management in these landscapes must be clearly

572 communicated to rural-amenity migrants with ecological restoration aspirations; the

573 importance of communicating the uncertainty of future outcomes is no better

574 exemplified by the success of Yellow Gums on Nick's property, and their dieback on

575 Trevor's property. Embracing uncertainty when dealing with landholders may increase

576 their preparedness for the types of 'surprise' outcomes experienced by Nick.

577

578

579

580

581

582

583

584

585

586

587

588

589

590

591

592

593

594

595 


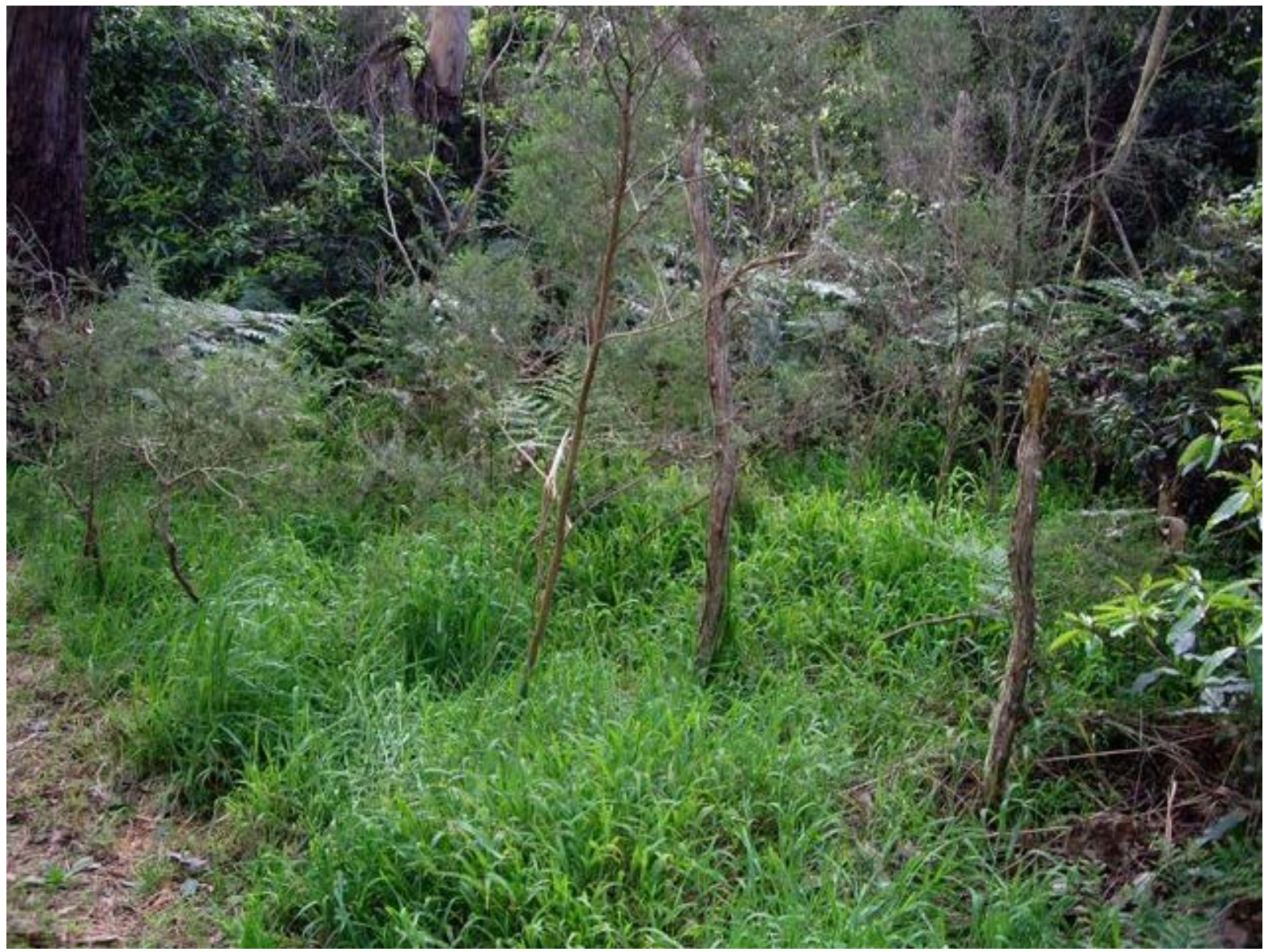

598 Figure 5. Martina cleared a patch of the 'invasive' Sweet Pittosporum (the green leafy tree seen in the 599 background) from around the small native tea trees (spp) seen in the foreground. Rather than triggering the growth of these native trees, Martina's disturbance of the site resulted in an infestation of pasture

603 Sweet Pittosporum (Pittosporum undulatum) has a dense, shrubby form. Its thick leaves

604 are so closely packed that few understory species can persist beneath its canopy for lack 605 of nutrients and light. When growing in close proximity to other Pittosporums, the thick 606 foliage produces a 'wall' of vegetation (visible in the background of Figure 5) that is 607 imposing and difficult to penetrate for humans and nonhumans alike.

609 Sweet Pittosporum has a dual ecological status in Victoria, listed as an endangered 610 species in one part of the state, while considered an invasive species outside its pre611 colonial range (Head, 2011; Lien \& Davison, 2010). Not only is this dual status 612 emblematic of the spatial and temporal construction of species nativeness, but its 613 physical presence also creates uncertainty for environmental management - should it 614 be retained or removed? In practice, the capacity for Sweet Pittosporum to spread 615 rapidly and establish quickly through forested areas, potentially out-competing other 616 middle and lower storey plants, has seen many local and regional environmental 
617 management institutions target it for removal. However, the question of whether to

618 remove or retain this species is a conundrum that is especially acute in areas that sit on

619 the boundary of what is considered its original range, such as the Bass Valley District

620 where Martina's property is located.

621

622 The growth of Sweet Pittosporum on Martina's property created a thick middle-storey

623 in what was previously an open forest with very few middle storey species. The decade

624 of drought mentioned earlier, along with the clearing of trees on an adjoining property

625 that once buffered her property from invasive plant spread, triggered rapid changes to

626 the local ecology. Martina's initial reaction to the establishment of Sweet Pittosporum

627 was to remove them in specific places where small native trees still persisted, to give

628 those native trees an opportunity to prosper. This was Martina's attempt to conserve

629 the ecology she had come to know during the decade she had inhabited her property.

630 Much to Martina's disappointment, her weed removal efforts proved futile, as rather

631 than encourage the growth and consolidation of native trees, the patches that were

632 cleared of Sweet Pittosporum were rapidly re-populated by pasture grass seed blown in

633 from nearby paddocks (Figure 5).

634

635 The successive establishment of different weed species caused Martina to question

636 whether her attempts to re-create the native ecology that she felt had been lost from the

637 landscape were either preferable or desirable. Observing and experiencing unexpected

638 responses of plants to goal-oriented human actions such as this can shift ideas and

639 approaches to environmental management when one occupies the space in which

640 interventions are conducted (Cooke \& Lane, 2015; Head \& Muir, 2006). The shift in

641 Martina's perception of appropriate management and ecological function was further

642 progressed when observing that Brown Thornbills (Acanthiza pusilla), a native bird

643 species, had established a nest in the Pittosporums that remained (Figure 5). The same

644 thick foliage that can envelop other native plants also provides the type of protected

645 habitat that is preferred by many small birds, including the Brown Thornbill

646 (Morcombe, 2004). Martina stopped removing pittosporums to retain their habitat

647 value, as 'that's actually where (the birds) were nesting'.

649 The habitat value and rapid spread of Pittosporum from a neighbouring property was a

650 pivotal catalyst for rupturing Martina's view of what was desirable management 
651 practice on her property. When walking down the road with Martina, she pointed out 652 how her property was only ever a remnant island of forest amidst a mosaic of farming, 653 rural-recreational and rural-residential properties. The realisation that she lived in a 654 'modified landscape' came as a consequence of the spread of invasive plants, rupturing 655 an implicit assumption that the property boundary was an impermeable barrier to 656 ecological processes like plant propagation and spread. The observation of birds nesting 657 in the same shrub species she had been removing caused Martina to see the danger of 658 being 'too avid a conservationist' and doggedly pursuing native ecologies. It was notable 659 that Martina's redemptive management aspirations persisted until the tangible process

660 of weed removal produced an unanticipated ecological response. Having experience this 661 response, and observed how non-native plant species could contribute to bird habitat, 662 Martina now felt she was contributing to the emergence of an ecology that was 663 concerned with function rather than species type (Hobbs, Higgs, \& Harris, 2009). The

664 lack of structural complexity in the ecological assemblage of highly modified landscapes 665 means that non-native species (and contested species like Pittosporum) can create 666 favourable habitat conditions for a diversity of bird species (Daniels and Kirkpatrick, 667 2006). Environmental management must consider how a more diverse range of species 668 could contribute to habitat creation in the Anthropocene, including species that might otherwise be the target of weed removal efforts in rural-amenity landscapes.

671 While the arrangement of ecologies differed across the three cases above, they generated unique actions and interventions by landholders, which exposed them to past people-plant relations. The long 'temporal arc' (Lien \& Davison 2010, p250) of the old

674 Sugar Gums across generations helped to facilitate their replanting in a new 675 arrangement. While the soil seed bank of Cocksfoot lay dormant for decades, it was its rapid and uniform materialisation that catalysed Nick's planting of eucalypts. For Pittosporums, their rapid spread and then growth to the point of manifesting as species habitat helped to enable their persistence in the landscape. These cases serve to highlight a challenge for environmental management practice in the Anthropocene; having identified the emergent dimension of ecologies, how does environmental management respond practically and conceptually to the ways in which embodied histories of landscape modification are structuring future ecological arrangements? 


\section{Progressing environmental management in rural-amenity landscapes}

686

\subsection{Landscape legacy - a temporal trajectory of people-plant relations}

688 The concept of 'landscape legacy' holds promise as a heuristic for operationalising the Anthropocene for environmental management in rural-amenity landscapes, by rendering the past and future as co-present (Figure 6 below). Wider applications of the notion of 'legacy' capture the idea of something being handed down from the past, with the potential to positively affect the future. As we have seen, rural-amenity migrants often want to leave their properties in better ecological condition than when they 694 purchased them. While aspirations for being a 'steward' of the land come in many forms 695 (Gill et al., 2010), a common thread is the desire to be active in creating and ultimately leaving a positive landscape legacy (Worrell and Appleby, 2000). Yet, efforts to realise this legacy involve environmental management in heavily modified landscapes. We can think about the way that landscape histories structure environmental management practices as a process of inheriting landscape legacy from the past. Thus, land management practice represents a moment where the bequeathing and inheriting of landscape legacies become entwined, as future aspirations and past practices embodied 703 in the landscape come together to produce new and often unanticipated ecologies.

\section{3}

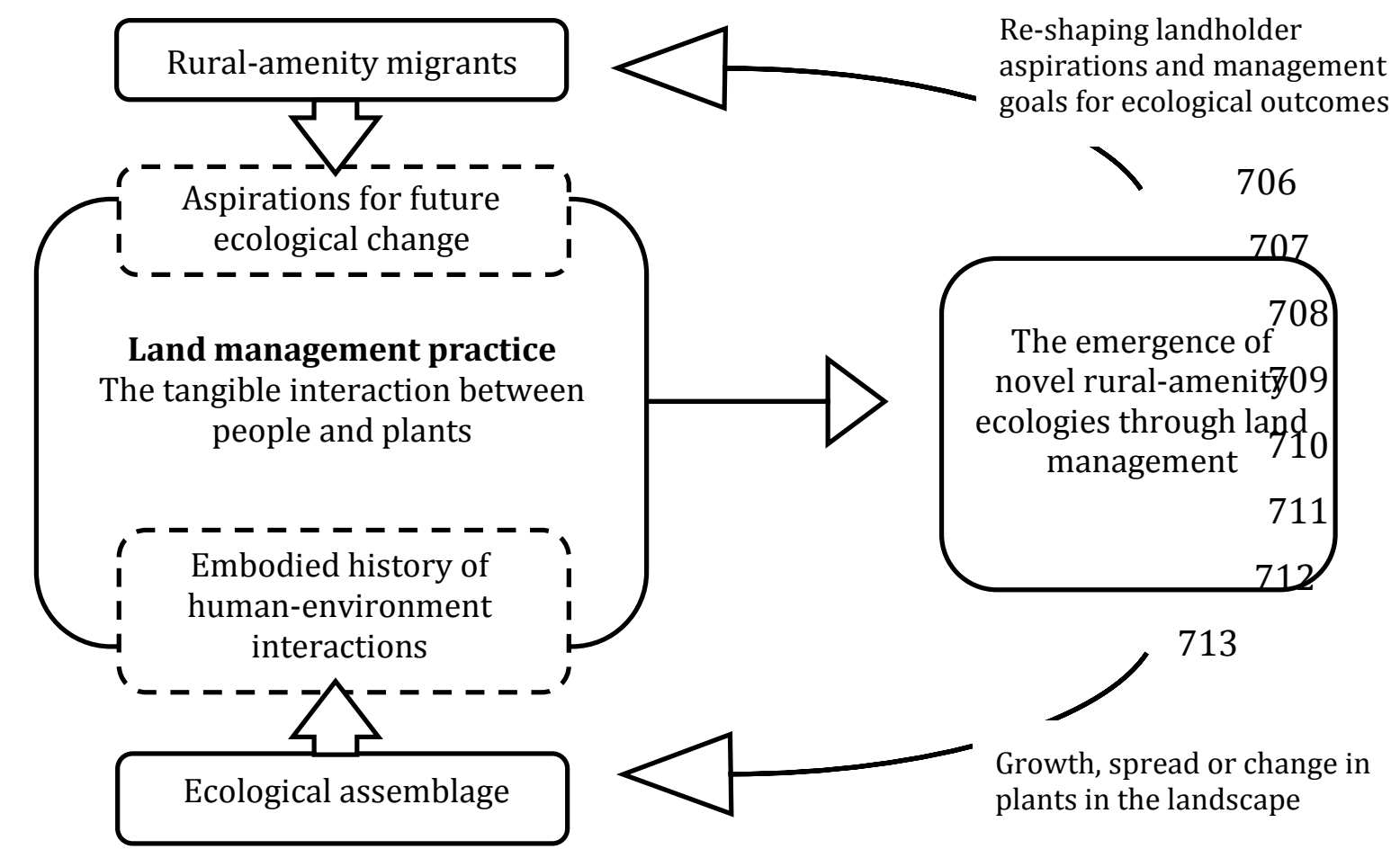

Figure 6. Landscape legacy characterises the transformative process of environmental management practice as a bringing together of past and future, as people and plants cohabit their surrounds and navigate the meshwork of embodied landscape histories in setting trajectories for future ecologies. 
721 Ingold's work on wayfaring is instructive for considering how amenity migrants are

722 encountering the structuring influence of past landscape legacies. We can conceive of

723 past-people plant relations embodied in the landscape as a practice that 'lays a trail'

724 (Ingold, 2011, p148) of human and nonhuman interaction in the landscape. These

725 meshworks of trails, or trajectories, are the structuring dimension that shapes the

726 ecological assemblages that amenity migrants encounter through environmental

727 management practice. Thus, through management practice, current landholders are

728 performing within the pathways that have been set down by previous inhabitants. As

729 we have seen, however, the trajectories of these trails are diffuse, and new paths can be

730 forged as people and plants inhabit landscapes in ways that push back against

731 embodied legacies. Therefore, landscape legacy is not pre-defined past 'transmitted

732 ready-made' (Ingold, 2011, 141) into the present, but a trail of human and non-human

733 interactions that sets a direction for current and future environmental management.

734 Engaging with the past as a trail being traversed by people in conjunction with non-

735 human actors positions past, present and future as a continuing trajectory of ecological

736 emergence. Thus, landscape legacy offers a means for displacing past ecological

737 benchmarks as a management objective, positioning the meshwork of interactions

738 embodied in the landscape as the historical touchstone for environmental management

739 in the Anthropocene.

740

741 Relating landscape legacy back to the experiences of participants above, Trevor can be

742 seen to have inherited a legacy through the Sugar Gums that were planted by the

743 previous owner of his property. Over time, Trevor's inherited legacy was translated into

744 a new legacy that is being projected forward through the growth of Sugar Gums in a

745 new assemblage - a new trail but one that has diverged from a past trajectory. The

746 legacy of farming on Nick's property dictated an ecological trajectory that Nick initially

747 resisted, before seeking to encourage a novel ecology that could persist within

748 parameters set by past activity. The legacy of landscape change in Martina's region saw

749 weed species establish and then become integral as bird habitat, directing Martina

750 towards management practices that maintained ecological function for fauna.

751 Consequently, as amenity migrants traced the trajectories of past landscape

752 interactions, they became co-participants in the production of future ecologies that

753 were already in the making. 
756 Evident in the experiences of all three research participants was that even when

757

758

759

760

761

762

763

764

765

766

767

768

769

770

771

772

773

774

775

776

777

778

779

780

781

782

783

784

785

786

787

788 redemptive ecological conservation was their initial land management aspiration, the process of inhabiting rural ecologies - but most importantly, being inhabited by them produced unanticipated ecological assemblages. Following Hobbs et al. (2006), we need to consciously position the pursuit of 'novel' environmental management centred on ecological function and process as the necessary starting point for land management, rather than the inevitable outcome. While Trevor, Martina and Nick eventually embraced novel ecological assemblages through trial-and-error, environmental management will be more effectively progressed with novelty as an aim. However, as we have seen, amenity migrants are part of the unfolding story of ecological novelty through landscape legacy; over time, the enfolding of the lives of people and plants produces ecologies that are unique in their assemblage and function (Head et al., 2014). These processes of past production must be reflected in environmental management efforts (Trigger et al., 2008). We need an approach that positions environmental management as a type of 'wild experiment' involving multiple agents working together under uncertainty (Lorimer \& Driessen, 2014; Hinchliffe, 2008). Thinking about management as a wild experiment can allow us to consider how best to create or maintain ecological form, process and function in ways that respond to ecological trajectories rather than ecological benchmarks.

Highlighting the power of people-plant interactions at the private property scale does reveal a danger that ecological assemblages could become constrained by that scale over the period of an individual's land tenure (Cooke and Lane, 2015). Progressing wild experiments in environmental management practice becomes even more critical in this context, as it highlights the importance of connecting landholders to knowledge and experience of ecological trajectories operating beyond the scale of their lived experience. For example, the predicted temperature increase for Australia of 2.5 degrees by 2070 even with significant emission reductions (CSIRO, 2014) may see the drought-tolerant Sugar Gums that Trevor planted become a more prominent component of novel rural-amenity ecologies. However, it may be preferable to progress a wild experiment where Sugar Gums are interspersed with other drought-tolerant shrubs and trees, to create a more complex and diverse ecology that provides habitat to a greater range of fauna. Preparedness amongst environmental management 
practitioners to progress such experiments collaboratively with landholders, rather

790 than insisting on pre-colonial native ecologies, may produce future ecologies that are more capable of responding to larger scale ecological processes.

792

\section{8. Conclusion}

794 Here we have explored how emergent rural ecologies provide an opportunity to 795 question how we currently conceptualise and practice environmental management in rural-amenity landscapes. The persistence of trees across generations of landholders, the dormancy and rapid propagation of soil seed banks and the habitat assemblages of weed species have shown how the lives of plants exemplify an extensive history of land use change. These altered landscapes structure a trajectory for ecological assemblages, as plants and plant interactions mediate the redemptive ecological aspirations of landholders. How we make space for the co-production of rural-amenity ecologies through environmental management, both conceptually and in practice, presents as a significant challenge.

Landscape legacy offers a way to conceive of how human and nonhuman actors are making and re-making rural-amenity ecologies. Rather than engaging with fixed historical baselines for conservation, landscape legacy positions environmental management as a process, with people positioned within a temporal trajectory of ecological change. While these trajectories can be re-shaped and re-orientated, the embodiment of trajectories through the 'meshwork' of people-plant relations over time serves as a pathway for the emergence of future ecological assemblages. Thus,

812 landscape legacy allows us to see contemporary environmental management practice as

813 a confluence of inheriting and bequeathing legacies through the co-habitation of people

814 and plants. Such a perspective invites some reflections for what open and reflexive environmental management might look like in the Anthropocene.

817 So, what might environmental management that is attentive to ecological function and

818 process look like, in light of landscape legacy? From the experiences of participants in

819 this case study, we must start with the ecologies that are already given and progress

820 carefully, assessing the current ecological assemblage and seeking to understand how

821 different species relate to one another. 'Progressing carefully' is an acknowledgement

822 that wild experiments in the Anthropocene are not an invitation to abdicate 
823 management to plants in the face of uncertainty. In fact, landscape legacy suggests the

824 opposite; we need to progress a more critical, process-focused, contingent framing for 825 environmental management, in light of the de-centering of benchmark ecologies. Such a 826 framing will be centred on the functional qualities of particular plants (and their inter827 relationships) and whether they are suited to increasing the diversity and habitat 828 complexity of ecologies in a given space (Head et al., 2015). Through this lens, wild 829 experiments in the Anthropocene direct a form of reflexive human agency that works 830 actively with the trajectories of ecological assemblages. An experimental trajectory for 831 environmental management will build on existing ecological diversity, while being 832 attentive to the structuring influence of historical pathways, to shape an Anthropocene 833 that is habitable for humans and nonhumans in the face of environmental change.

835 A diverse trajectory of ecologies will need to be contemplated in order to meet present 836 and imminent socio-ecological challenges, at local to global scales (Head, 2011; Young, 837 2014). As we have shown, there is a great deal of uncertainty in knowing which species 838 will flourish and in what arrangement, and how the experiences of the people who 839 inhabit these landscapes will contribute to that flourishing (Lorimer \& Driessen, 2014;

840 Hinchliffe, 2008). A wild experiment framing allows environmental management to 841 respond to the observed behavior of plants and their interaction with the broader 842 ecological assemblage as those ecologies are taking shape. Given management is already 843 progressing at the property scale, there is a need to bring this experimentation into the 844 theory and practice of environmental management at an institutional level. Rural-

845 amenity landscapes are firmly of the Anthropocene in terms of their historical 846 modification and uncertain future trajectory, making them a productive space for novel 847 and reflexive environmental management.

849 Acknowledgements

850 This paper was written with support from the Australian Government's National 851 Environmental Research Program and the Australian Research Council Centre of 852 Excellence for Environmental Decisions. Thanks to A. Backstrom for species 853 identification advice. 
879

880

881

882

883

884

885

886

887

888

889

890

891

892

893

894

895

896

897

898

899

900

901

902

903

904

905

906

907

\section{References}

ABS (Australian Bureau of Statistics). (2006). Bass Coast Shire Council community profile data. Retrieved August 2, 2012, from http://profile.id.com.au/bass-coast/industries?WebID=130\&DataType=en

Abrams, J., Gill, N., Gosnell, H., Klepeis, P., 2012. Re-creating the rural, reconstructing nature: An international literature review of the environmental implications of amenity migration. Conserv. Soc. 10, 270. doi:10.4103/0972-4923.101837

Argent, N., Tonts, M., Jones, R., Holmes, J., 2010. Demographic Change in Australia's Rural Landscapes. Victoria, Landscape Series 12, 23-44. doi:10.1007/978-90-4819654-8

Barr, N. (2005). The changing social landscape of rural Victoria. Melbourne: Department of Primary Industries Victoria.

Barthel, S., Folke, C., Colding, J., 2010. Social-ecological memory in urban gardensRetaining the capacity for management of ecosystem services. Glob. Environ. Chang. 20, 255-265. doi:10.1016/j.gloenvcha.2010.01.001

Cadieux, K.V., 2011. Competing discourses of nature in exurbia. GeoJournal 76, 341-363. doi:10.1007/s10708-009-9299-0

Castree, N., 2014. The Anthropocene and Geography I: The Back Story. Geogr. Compass 8, 436-449. doi:10.1111/gec3.12141

CCMA. (2003). Corangamite regional catchment strategy 2003-2008. Colac: Corangamite Catchment Management Authority.

Chew, M., Hamilton, A., 2011. The rise and fall of biotic nativeness: a historical perspective, in: Fifty Years of Invasion Ecology. The Legacy of Charles Elton. Blackwell, pp. 35-48.

Cocklin, C., Dibden, J., 2006. From market to multifunctionality? Land stewardship in Australia. Geogr. J. 172, 197-205.

Cooke, B., Lane, R., 2015. How do amenity migrants learn to be environmental stewards of rural landscapes? Landsc. Urban Plan. 134, 43-52. doi:10.1016/j.landurbplan.2014.10.006

CSIRO. (2014). State of the climate 2014. CSIRO and The Australian Bureau of Meteorology.

Curry, G.N., Koczberski, G., Selwood, J., 2001. Cashing Out, Cashing In: Rural change on the south coast of Western Australia. Aust. Geogr. 32, 109-124. doi:10.1080/00049180020036268

Daniels, G.D., Kirkpatrick, J.B., 2006. Does variation in garden characteristics influence the conservation of birds in suburbia? Biol. Conserv. 133, 326-335. doi:10.1016/j.biocon.2006.06.011

Doody, B.J., Perkins, H.C., Sullivan, J.J., Meurk, C.D., Stewart, G.H., 2014. Performing weeds: Gardening, plant agencies and urban plant conservation. Geoforum 56, 124-136. doi:10.1016/j.geoforum.2014.07.001

Ellis, E., 2015. Ecology in an Anthropogenic Biosphere. Ecol. Monogr.

Ellis, E.C., 2013. Sustaining biodiversity and people in the world's anthropogenic biomes. Curr. Opin. Environ. Sustain. 5, 368-372. doi:10.1016/j.cosust.2013.07.002

Future Farm Industries CRC. (2011). Management guide to minimise environmental weed risk: Cocksfoot. Retrived from: www.futurefarmonline.com.au/about/weedrisk

Gammage, B. (2011). The biggest estate on earth: how Aborigines made Australia. Allen and Unwin: Sydney. 
Gill, N., Klepeis, P., Chisholm, L., 2010. Stewardship among lifestyle oriented rural landowners. J. Environ. Plan. Manag. 53, 317-334. doi:10.1080/09640561003612890

Ginn, F., 2008. Extension, subversion, containment: eco-nationalism and (post) colonial nature in Aotearoa New Zealand. Trans. Inst. Br. Geogr.

Gosnell, H., 2011. Amenity migration: diverse conceptualizations of drivers, socioeconomic dimensions, and emerging challenges. GeoJournal 76, 303-322. doi:10.1007/s10708-009-9295-4

Gosnell, H., Haggerty, J., Travis, W., 2006. Ranchland Ownership Change in the Greater Yellowstone Ecosystem, 1990-2001: Implications for Conservation. Soc. Nat. Resour. 19, 743-758. doi:10.1080/08941920600801181

Hamilton, L (2001). The Sugar Gum story: the marketing success of a humble shelter tree. The Regional Institute Ltd.

Harris, J., Hobbs, R., Higgs, E., Aronson, J., 2006. Ecological restoration and global climate change. Restor. Ecol. 14, 170-176.

Head, L., 2011. Decentring 1788 : Beyond Biotic Nativeness. Geogr. Res. 1-13. doi:10.1111/j.1745-5871.2011.00746.x

Head, L., Atchison, J., 2008. Cultural ecology: emerging human-plant geographies. Prog. Hum. Geogr. 33, 236-245. doi:10.1177/0309132508094075

Head, L., Atchison, J., Phillips, C., 2014. The distinctive capacities of plants: re-thinking difference via invasive species. Trans. Inst. Br. Geogr. n/a-n/a. doi:10.1111/tran.12077

Head, L., Larson, B., Hobbs, R., Atchison, J., Gill, N., Kull, C., Rangan, H., 2015. Living with invasive plants in the Anthropocene: the importance of understanding practice and experience. Conserv. Soc. 1-21.

Head, L., Muir, P., 2006. Suburban life and the boundaries of nature : resilience and rupture in Australian backyard gardens. Trans. Inst. Br. Geogr. 31, 505-524.

Hinchliffe, S., 2008. Reconstituting nature conservation: Towards a careful political ecology. Geoforum 39, 88-97. doi:10.1016/j.geoforum.2006.09.007

Hobbs, R., Arico, S., Aronson, J., 2006. Novel ecosystems: theoretical and management aspects of the new ecological world order. Glob. Ecol. Biogeogr. 15, 1-7. doi:10.1111/j.1466-822x.2006.00212.x

Hobbs, R.J., Higgs, E., Harris, J. a, 2009. Novel ecosystems: implications for conservation and restoration. Trends Ecol. Evol. (Personal Ed. 24, 599-605. doi:10.1016/j.tree.2009.05.012

Holmes, J., 2006. Impulses towards a multifunctional transition in rural Australia: Gaps in the research agenda. J. Rural Stud. 22, 142-160. doi:10.1016/j.jrurstud.2005.08.006

Ingold, T. (2011).Being Alive: Essays on Movement, Knowledge and Description. Routledge: London.

Ingold, T. (2007). Lines: A Brief History. Routledge, Oxon: UK.

Ingold, T. (2000). The perception of the environment: essays on livelihood, dwelling and skill. London: Routledge.

Ingold, T. (1993). The temporality of the landscape. World Archaeology, 25(2), 152-174. doi/abs/10.1080/00438243.1993.9980235

Jackson-Smith, D., Kreuter, U., 2005. Understanding the multidimensionality of property rights orientations: evidence from Utah and Texas ranchers. Soc. Nat. Resour. 587610. doi:10.1080/08941920590959578

Jones, O., \& Cloke, P. (2008). Non-human agencies: trees in place and time. In, (Eds.) C. Knappett \& L. Malafouris. Material agency: towards a non-anthropocentric approach. New York: Springer, p. 79-96. 
982

983

984

985

986

987

988

989

990

991

992

993

994

995

996

997

998

999

1000

1001

1002

1003

1004

1005

1006

1007

1008

Klepeis, P., Gill, N., Chisholm, L., 2009. Emerging amenity landscapes: Invasive weeds and land subdivision in rural Australia. Land use policy 26, 380-392. doi:10.1016/j.landusepol.2008.04.006

Knapp, C.N., Fernandez-Gimenez, M.E., 2009. Knowledge in Practice: Documenting Rancher Local Knowledge in Northwest Colorado. Rangel. Ecol. Manag. 62, 500509. doi:10.2111/08-175.1

Knoot, T.G., Schulte, L. a, Rickenbach, M., 2010. Oak conservation and restoration on private forestlands: negotiating a social-ecological landscape. Environ. Manage. 45, 155-64. doi:10.1007/s00267-009-9404-7

Kvale, S., \& Brinkmann, S. (2009). Interviews: learning the craft of qualitative research interviewing. Thousand Oaks, California: Sage.

Larsen, S., Sorenson, C., McDermott, D., Long, J., Post, C., 2007. Place Perception and Social Interaction on an Exurban Landscape in Central Colorado. Prof. Geogr. 59, 421-433. doi:10.1111/j.1467-9272.2007.00632.x

Lien, M.E., Davison, A., 2010. Roots, Rupture and Remembrance: The Tasmanian Lives of the Monterey Pine. J. Mater. Cult. 15, 233-253. doi:10.1177/1359183510364078

López-i-Gelats, F., Tàbara, J.D., Bartolomé, J., 2009. The rural in dispute: Discourses of rurality in the Pyrenees. Geoforum 40, 602-612.

doi:10.1016/j.geoforum.2009.04.008

Lorimer, J., Driessen, C., 2014. Wild experiments at the Oostvaardersplassen: rethinking environmentalism in the Anthropocene. Trans. Inst. Br. Geogr. 39, 169-181. doi:10.1111/tran.12030

Marris, E. (2011). The rambunctious garden: saving nature in a post-wild world. Bloomsbury: New York.

Marsden, T., Murdoch, J., Lowe, P., and Ward, N. (2003). The differentiated countryside. London: Routledge.

Massey, D. (2005). For Space. London: Sage.

Mastnak, T., Elyachar, J., Boellstorff, T., 2014. Botanical decolonization: rethinking native plants. Environ. Plan. D Soc. Sp. 32, 363-380. doi:10.1068/d13006p

Mendham, E., Curtis, A., 2010. Taking Over the Reins: Trends and Impacts of Changes in Rural Property Ownership. Soc. Nat. Resour. 23, 653-668. doi:10.1080/08941920801998893

Mendham, E., Curtis, A., Millar, J., 2012. The Natural Resource Management Implications of Rural Property Turnover. Ecol. Soc. 17, 5. doi:10.5751/ES-05071-170405

Morcombe, M (2004). Field guide to Australian birds. Steve Parish Publishing: Gold Coast.

Paquette, S., Domon, G., 2003. Changing ruralities, changing landscapes: exploring social recomposition using a multi-scale approach. J. Rural Stud. 19, 425-444. doi:10.1016/S0743-0167(03)00006-8

Power, E.R., 2005. Human-Nature Relations in Suburban Gardens. Aust. Geogr. 36, 3953. doi:10.1080/00049180500050847

Race, D., Luck, G.W., Black, R., 2010. Demographic Change in Australia's Rural Landscapes, in: Luck, G.W., Black, R., Race, D. (Eds.), North, Landscape Series. Springer Netherlands, Dordrecht, pp. 1-22. doi:10.1007/978-90-481-9654-8

Ragusa, A.T. (2010). Seeking trees or escaping traffic? Socio-cultural factors and 'tree change' migration in Australia. in: Luck, G.W., Black, R., Race, D. (Eds.), North, Landscape Series. Springer Netherlands, Dordrecht, pp. 1-22. doi:10.1007/978-90481-9654-8

Robbins, P., Moore, S. a., 2013. Ecological anxiety disorder: diagnosing the politics of the Anthropocene. Cult. Geogr. 20, 3-19. doi:10.1177/1474474012469887 
Rose, D.B. (1996). Nourishing terrains: Australian Aboriginal view of landscape and wilderness. Australian Heritage Commission: Canberra.

Rosenthal, G. (2004). Biographical research. In (Eds.) C. Seale, G. Gobo, J. F. Gubrum, \& D. Silverman, Qualitative Research Practice. Thousand Oaks, California: Sage. p. 48-65.

Strang, V. (2010). Mapping histories: cultural landscapes and walkabout methods. In A. Smith, \& S. Aswani (Eds.), Environmental social science: methods and research design (pp. 132-156). Cambridge: Cambridge University Press.

Tonts, M., Argent, N., Plummer, P., 2011. Evolutionary Perspectives on Rural Australia. Geogr. Res. 50, 291-303. doi:10.1111/j.1745-5871.2011.00745.x

Trigger, D., Mulcock, J., Gaynor, A., Toussaint, Y., 2008. Ecological restoration, cultural preferences and the negotiation of "nativeness" in Australia. Geoforum 39, 12731283. doi:10.1016/j.geoforum.2007.05.010

Urquhart, J., Courtney, P., 2011. Seeing the owner behind the trees: A typology of smallscale private woodland owners in England. For. Policy Econ. 13, 535-544. doi:10.1016/j.forpol.2011.05.010

Van Auken, P.M., 2010. Seeing, not Participating: Viewscape Fetishism in American and Norwegian Rural Amenity Areas. Hum. Ecol. 38, 521-537. doi:10.1007/s10745010-9323-5

Walker, P., Marvin, S., Fortmann, L., 2003. Landscape changes in Nevada County reflect social and ecological transitions. Calif. Agric. 57, 115-121.

Walker, P.A., Marvin, S.J., Fortmann, L.P., 2003. Landscape changes in Nevada County reflect social and ecological transitions. Environ. Toxicol. Chem. 115-121.

Wang, Y., Jiang, D., Toshio, O., Zhou, Q., 2013. Recent advances in soil seed bank research. Contemp. Probl. Ecol. 6, 520-524. doi:10.1134/S1995425513050181

Worrell, R., Appleby, M.C., 2000. Stewardship of Natural Resources : Definition , Ethical and Practical Aspects. J. Agric. Environ. Ethics 12, 263-277.

Young, K.R., 2014. Biogeography of the Anthropocene: Novel species assemblages. Prog. Phys. Geogr. doi:10.1177/0309133314540930

Yung, L., Belsky, J.M., 2007. Private Property Rights and Community Goods: Negotiating Landowner Cooperation Amid Changing Ownership on the Rocky Mountain Front. Soc. Nat. Resour. 20, 689-703. doi:10.1080/08941920701216586 